\title{
Relationship Between Sitting Height Measurements and Standing Height: A Prospective Regional Study among Adolescents in the Southern Region of Kosovo
}

\author{
Relación entre las Medidas de la Altura Sentada y la Altura de Pie: Un Estudio \\ Regional Prospectivo entre Adolescentes de la Región Sur de Kosovo
}

Bojan Masanovic ${ }^{1}$; Fitim Arifi ${ }^{2}$ \& Jovan Gardasevic ${ }^{1}$

MASANOVIC, B.; ARIFI, F. \& GARDASEVIC, J. Relationship between sitting height measurements and standing height: A prospective regional study among adolescents in the southern region of Kosovo. Int. J. Morphol., 38(6):1681-1685, 2020.

SUMMARY: The purpose of this research is to determine a regression equation for the estimation of stature from sitting height measurements in the Southern Region of Kosovo. This research was carried out on 225 individuals (120 male and 105 female). The anthropometric measurements were taken according to the ISAK protocol. The relationships between standing height and sitting height measurements were determined using simple correlation coefficients at a $95 \%$ confidence interval. A comparison of means of standing height and sitting height between genders was performed using a t-test. After that, a linear regression analysis was carried out to examine the extent to which sitting height can reliably predict standing height. The results revealed that Southern Kosovan males are $178.61 \pm 5.73$ $\mathrm{cm}$ tall and have a sitting height of $94.05 \pm 3.09 \mathrm{~cm}$, while Southern Kosovan females are $165.33 \pm 4.46 \mathrm{~cm}$ tall and have a sitting height of $89.34 \pm 2.50 \mathrm{~cm}$. The results have shown that both genders made Southern-Kosovans a tall group, taller than the general Kosovan population. This research study confirmed that sitting height reliably predicts stature in both genders of adolescents in the Southern Region of Kosovo and revealed a very useful finding for physical anthropologists and experts from related fields.

KEY WORDS: Prediction; Measures; Stature; Sitting Height; Kosovan.

\section{INTRODUCTION}

This study was conducted to analyze standing height in Southern Kosovan adolescents and the possibility of its prediction utilizing sitting height measurements. Kosovo extends over an area of 1,397 square kilometres and has a population of 331,670 inhabitants: the average density per square kilometre is 240 inhabitants (Arifi et al., 2017). Administratively, it is subdivided into five regions (Eastern, Western, Northern, Southern, and Central), and contains five municipalities (Dragas, Malisheva, Mamusha, Prizren, and Suva Reka/Suharekë) (Masanovic et al., 2018). The territory of Kosovo is small but has a highly varied terrain. Most of Kosovo's borders are dominated by mountains and high grounds (Popovic et al., 2017). The most noticeable topographical features are the Albanian Alps, which are a continuation of the Dinaric Alps; they pass through the west along the border with Albania and Montenegro (Gardasevic et al., 2019). It is widely known that standing height and body proportions are specific with regard to populations li- ving on Dinarides (Starc et al., 2019). People from the Dinaric Alps were recognized as tall people by European anthropologists more than a century ago (Grasgruber et al., 2019). Based on that, one possible conclusion is that this fact might influence the main objective of this study, because of the soil type, as well as other socio social, economic and geographical characteristics as a potential influencing factor (Gardasevic et al., 2017).

When assessing the functional state of children's or adults' bodies, physicians start by measuring standing height, body weight, body mass index, or body proportions. If these data measurements are repeated regularly, a database will be formed, based on which it will be easy to create a complete idea about young people's development, also about the health and current working ability of adults. Likewise, nutritionists may measure the basal metabolism level of a person based on this data, and physicians may safely

\footnotetext{
${ }^{1}$ University of Montenegro, Faculty for Sport and Physical Education, Niksic, Montenegro.

${ }^{2}$ University of Tetovo, Faculty of Physical Education, Tetovo, North Macedonia.
} 
recommend drug dosages to the patient (Harris \& Benedict, 1918). Finally, body height data, along with some other data, is helpful for sports science experts to predict final growth, which is critical data for talent identification in sport (Bjelica et al., 2020a,b). However, if a person has spinal column deformity, bone fractures and similar problems, or if he/she has a lower limb amputated, measuring actual standing height is difficult. The same is true if a person cannot keep upright or maintain posture due to ageing. In such cases, there is a need to predict objective body height indirectly, which can be done by using certain anthropometric measures (Popovic, 2019). The most reliable parameter for indirect standing height determination is the relation between arm span and standing height; all contemporary studies confirm the validity of this (Brown et al., 2002; Popovic et al., 2013). The following are considered the most reliable parameters: the relation between foot length and standing height, and the relation between sitting height and standing height (Kanchan et al., 2008). It is necessary to note that the relation between foot length and standing height is recommended if standing height predictions about adolescents are made. The reason is that short foot bones ossify faster and therefore, in this period, this dimension is the most approximate to the final size (Jakhar et al., 2010). The relation between sitting height and standing height is the recommended parameter if it is necessary to predict adults' body height (Leung et al., 1996), because the growth rate is not the same for all parts of the body, so in the first stage of puberty, the limbs grow faster, while torso reaches its final dimension later.

However, when indirectly determining body height, the fact that differences exist between racial and ethnic groups in terms of the body proportion and relation between particular anthropometric parameters and body height causes problems (Popovic et al., 2013; Steele \& Chenier, 1990; Reeves et al., 1996; Popovic et al., 2015). If taken as an example, the Cormic index, which represents the relation between sitting height and standing height, it will be seen that European residents are different from those of other continents. According to the Cormic index, the relation mentioned above in the European population is $52 \%$, while it is about $51 \%$ in the African population which means they have slightly longer legs on average. In contrast, in Asian populations, the Cormic index is in the range of 53\%-54\%, which means they have shorter legs. Lastly, the Cormic index of Australian Aborigines is between $45 \%$ and $49 \%$, indicating that they have longer legs than others (Ukwuma, 2009).

However, the next circumstance is the fact that many new studies prove regional variations regarding the body height of the residents of Montenegro and Kosovo (Arifi et al.; Popovic, 2017; Masanovic et al., 2019a). These variations might be the case with stature predictions using sitting height, mostly because one part of Kosovo lies in the area of a mountain range known as the Dinaric Alps, area whose population has a specific physique; for over a century, they have been the tallest people in the world (Popovic, 2017).

Taking into account this data, researchers agree that it is necessary to create specific formulas for indirect body height calculation using other indirect parameters for each race and ethnic group individually, also for different regions (Datta Banik, 2011; Quanjer et al., 2014; Masanovic et al., 2019b). In accordance with that, this study was conducted with a purpose of analyzing standing height and the possibility of its prediction utilizing sitting height measurements in adolescents in Southern region of Kosovo.

\section{MATERIAL AND METHOD}

The study included 225 final year high-school students (120 male and 105 female) from the Southern Region of Kosovo as subjects. This group was selected for two reasons: first, the fact that the growth of an individual ceases by this age and, second, age-related loss in standing height at this age does not exist. The average age of the male subject was $18.40 \pm 0.56$ years old (range $18-20$ years), while the average age of the female subject was $18.36 \pm 0.50$ years old (range 18-20 years). It is important to highlight that the researchers have excluded from the data analysis individuals with physical deformities as well as those without informed consent. Another exclusion criterion was being non-Southern Kosovan.

Standing height and sitting height were measured according to the protocol of the International Society for the Advancement of Kinanthropometry (Marfell-Jones et al., 2006). Measurement was conducted by trained measurer, while the quality of their performance was evaluated against the prescribed ISAK Manual. Lastly, the age of each subject was reached directly from the birthdays.

The analysis was performed by using the Statistical Package for Social Sciences SPSS, version 20.0 (Chicago, IL, USA). Means and standard deviations (SD) were obtained for both anthropometric variables. A comparison of means of standing height and sitting height between genders was performed using a t-test. The relationships between standing height and sitting height were determined using simple correlation coefficients at a $95 \%$ confidence interval. Then, a linear regression analysis was carried out to examine the extent to which the sitting height can reliably predict standing height. Statistical significance was set at $\mathrm{p}<0.05$. 


\section{RESULTS}

The overview of anthropometric measurements in both genders is presented in Table I. The mean of the standing height for male was $178.61 \pm 5.73$ centimeters, and sitting height was $94.05 \pm 3.09$ centimeters, while for female the standing height was $165.33 \pm 4.46$ centimeters, and sitting height was $89.34 \pm 2.50$ centimeters. The gender difference between standing height and sitting height measurements was statistically significant (standing height: $t=19.183$; $\mathrm{p}<.000$, and sitting height: $\mathrm{t}=12.438 ; \mathrm{p}<.000)$.

Table I. Anthropometric measurements of the study subjects

\begin{tabular}{ccc}
\hline \multirow{2}{*}{ Subjects } & $\begin{array}{c}\text { Standing Height Range } \\
(\text { Mean } \pm \text { SD })\end{array}$ & $\begin{array}{c}\text { Sitting Height Range } \\
(\text { Mean } \pm \text { SD) }\end{array}$ \\
\cline { 2 - 3 } Male & $164.6-192.3$ & $84.4-100.8$ \\
& $(178.61 \pm 5.73)$ & $(94.05 \pm 3.09)$ \\
Female & $158.0-184.0$ & $83.5-97.0$ \\
& $(165.33 \pm 4.46)$ & $(89.34 \pm 2.50)$ \\
\hline
\end{tabular}

The simple correlation coefficients and their $95 \%$ confidence interval analysis between the anthropometric measurements are presented in Table II. The relationship between standing height and sitting height were significant $(\mathrm{p}<0.000)$ and high in this sample, regardless of gender (male: 0.732; female: 0.624).

Table II. Correlation between standing height and sitting height of the study subjects

\begin{tabular}{cccc}
\hline Subjec ts & $\begin{array}{c}\text { Correlation } \\
\text { Coefficient }\end{array}$ & $\begin{array}{c}95 \% \\
\text { interval }\end{array}$ & $\begin{array}{c}\text { Significance } \\
\text { p-value }\end{array}$ \\
\hline Male & 0.732 & $0.608-0.856$ & $<0.000$ \\
Female & 0.624 & $0.471-0.777$ & $<0.000$ \\
\hline
\end{tabular}

The results of the linear regression analysis are presented in Table III. The first model was extracted by including age as a covariate. However, the contribution of age was insignificant; therefore, age was excluded, and estimates were obtained as univariate analysis. The high values of the regression coefficient (male: 0.732; female: 0.624) signify that sitting height notably predicts standing height in both Southern-Kosovan genders (male: $t=11.675$, $\mathrm{p}<0.000$; female: $\mathrm{t}=8.102, \mathrm{p}<0.000$ ), which confirms the Rsquare ( \%) for the male (53.6) as well as for the female (38.9).

Table III. Results of linear regression analysis where the sitting height predicts the standing height

\begin{tabular}{cccccr}
\hline Subjects & $\begin{array}{c}\text { Regression } \\
\text { Coefficient }\end{array}$ & $\begin{array}{c}\text { Standard } \\
\text { Error (SE) }\end{array}$ & $\begin{array}{c}\text { R-square } \\
(\%)\end{array}$ & t-value & p-value \\
\hline Male & 0.732 & 3.922 & 53.6 & 11.675 & 0.000 \\
Female & 0.624 & 3.498 & 38.9 & 8.102 & 0.000 \\
\hline
\end{tabular}

The relationship between sitting height measurements and standing height among the above models is sketched as a scatter diagram (Fig. 1).

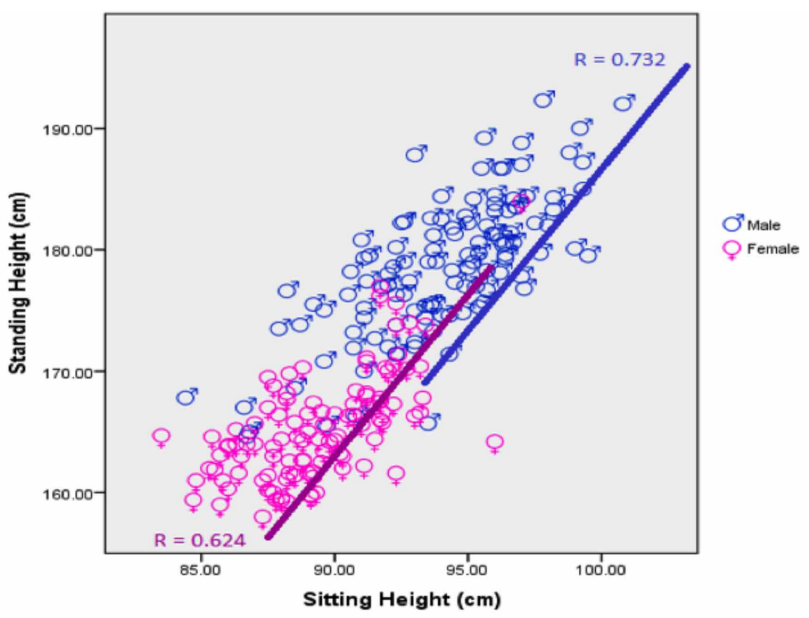

Fig. 1. Scatter diagram and relationship between sitting height measurements and standing height among both sexes.

\section{DISCUSSION}

The measurement of stature based on different anthropometric parameters has been applied and understood since the 19th century in physical anthropology. Initially, there were misunderstandings about which anthropometric parameter was the best predictor, but nowadays, it is agreed that it is the relationship between body height and arm span (Mohanty et al., 2001; Arifi et al.; Masanovic et al., 2020). The next most reliable body height predictors are considered to be foot length and sitting height, but other anthropometric indicators may be used, such as knee height, tibia length, scapula length, hand length, and similar. Use of all these predictors is justified when the arm span cannot be provided (Popovic, 2019).

This study confirms a very high linear correlation between standing height and sitting height in both Northern Kosovan genders ( $r=0.735$ in males; $r=0.586$ in females), which means that this anthropometric parameter may be considered to be a reliable body height predictor. Similar studies implemented on residents of the Netherlands, Indonesia and Spain confirm this statement (Fredriks et al., 2005; Fatmah, 2010; Arriba Munoz et al., 2013).

Furthermore, it is generally known that certain anthropometric measurements may vary depending on racial affiliation, and from one ethnic group to another (Steele \& Chenier; Reeves et al.; Popovic et al., 2013). Increasing numbers of research studies confirming significant differences 
in previously mentioned anthropometric parameters between ethnically related people who live in different regions, that is, on territories with different geographical characteristics. Some recent studies confirmed the existence of regional differences in body height for members of the same ethnic group (Popovic, 2017; Masanovic et al., 2019a), and the same is confirmed for foot length and standing height ratio (Popovic et al., 2017), also for tibia length and standing height ratio (Gardasevic, 2019).

The next question is whether the same applies to the relation between sitting height and standing height. The correlation coefficient for sitting height and standing height ratio of the population of Eastern Kosovo ( $\mathrm{r}=0.743$ in males and $r=0.705$ in females), and Western Kosovo ( $r=0.661$ in males and $\mathrm{r}=0.614$ in females) (Gardasevic, 2018; Masanovic et al., 2019c), are different from Southern-Kosovans ( $\mathrm{r}=0.732$ in males and $\mathrm{r}=0.624$ in females), which confirms the existence of differences and points the need to create specific formulas for indirect body height calculation when the sitting height parameter is used. Although correlation coefficients have similar values, the estimation equations, which are obtained in the Southern Kosovans, considerably differ from populations from other regions in Kosovo, which confirms that it is necessary to develop separate standing height models for each population on account of regional variations in Kosovo. The necessity for developing separate regional models for both genders in Kosovo was also based at the fact that entire Kosovo does not fall into Dinaric Alps racial classification (Mustafa et al., 2012), and that the southern part of this area, for the most part, does not lie on this mountain range.

It is necessary to note that one study limitation may be the structure of respondents in the selected sample and the fact that residents for the most of Kosovo had not reached their full genetic potential so that positive secular trend may lead to average standing height changes, including body proportion changes. There are studies that state that final grade high-school students are still in a stage of growth and development (Szollosi, 1998; Wronka \& Pawlinska-Chmara, 2009; Grasgruber et al.), but studies conducted in Montenegro contradict this claim, because a standing height difference between university students and final grade high-school students was not found (Bjelica et al., 2012, Popovic et al., 2017). Therefore, a similar situation can be expected with the population of Kosovo, "given the certain similarities between Montenegrins and Kosovars, or some common specific features in relation to other populations in the region" (Popovic, 2019). Regarding a secular trend, Kosovo has not reached its full genetic potential yet. In low-income countries, improving health conditions drives increases in stature, and some authors claim that this increase in height "has been due almost entirely to longer legs" (Tanner et al., 1982) and that it will lead to changes in body proportions. That is why populations like this need to update height-based prediction equations periodically. It is expected that the secular changes influencing standing height will increase in the following two or three decades; one study asserted that that update data period should be every ten years (Kubota et al., 2014), which means that continuous monitoring is necessary.

MASANOVIC, B.; ARIFI, F. \& GARDASEVIC, J. Relación entre las medidas de la altura sentada y la altura de pie: un estudio regional prospectivo entre adolescentes de la región sur de Kosovo. Int. J. Morphol., 38(6):1681-1685, 2020.

RESUMEN: El objetivo de este trabajo fue determinar una ecuación de regresión para la estimación de la estatura a partir de mediciones de la altura sentada en la Región Sur de Kosovo. La investigación se realizó en 225 individuos (120 hombres y 105 mujeres). Las medidas antropométricas se tomaron según el protocolo ISAK. Se determinaron las relaciones entre la altura de pie y la altura sentada utilizando coeficientes de correlación simples con un intervalo de confianza del $95 \%$. Se realizó una comparación de las medias de la altura de pie y la altura sentada entre sexos mediante una prueba t. Además, se llevó a cabo un análisis de regresión lineal para la estimar la confiabilidad de la medición de altura de pie, considerando la altura sentada. Los resultados indican que los varones del sur de Kosovo miden 178,61 $\pm 5,73 \mathrm{~cm}$ de altura y tienen una altura sentada de $94,05 \pm 3,09 \mathrm{~cm}$, mientras que las mujeres miden $165,33 \pm 4,46 \mathrm{~cm}$ de altura y tienen una altura sentada de $89,34 \pm 2,50 \mathrm{~cm}$. Los resultados han demostrado que ambos sexos kosovares del sur son más altos que la población general de Kosovo. Este estudio confirmó que la altura sentada predice de manera confiable la estatura de ambos sexos en adolescentes de la región sur de Kosovo y reveló un hallazgo útil para los antropólogos físicos y los expertos de áreas relacionadas.

PALABRAS CLAVE: Predicción; Medidas; Estatura; Altura de asiento; Kosovar.

\section{REFERENCES}

Arifi, F.; Sermaxhaj, S.; Zejnullahu-Raçi, P.; Alaj, I. \& Metaj, Z. Stature and its estimation utilizing arm span measurements of both gender adolescents from northern region in Kosovo. Acta Kinesiol., 11(1):49$52,2017$.

Arriba Munoz, A.; Dominguez Cajal, M.; Rueda Caballero, C.; Labarta Aizpun, J. I.; Mayayo Dehesa, E. \& Ferrandez Longas, A. Sitting/standing height ratio in Spanish children from birth to adulthood. Arch. Argent. Pediatr., 111(4):309-14, 2013.

Bjelica, D.; Gardasevic, J.; Masanovic, B. \& Vasiljevic, I. Soccer National Team of Kosovo (U19) in comparison with other players in this country with regards to anthropometric characteristics and body composition. Int. J. Appl. Exerc. Physiol., 9(1):1-7, 2020a.

Bjelica, D.; Masanovic, B. \& Krivokapic, D. A comparative study of anthropometric measurements and body composition between junior football and basketball players from the Serbian National League. Balt. J. Health Phys. Act., 12(1):11-9, 2020b. 
Bjelica, D.; Popovic, S.; Kezunovic, M.; Petkovic, J.; Jurak, G. \& Grasgruber, P. Body height and its estimation utilizing arm span measurements in Montenegrin adults. Anthropol. Noteb., 18(2):69-83, 2012.

Brown, J. K.; Feng, J. Y. \& Knapp, T. R. Is self-reported height or arm span a more accurate alternative measure of height? Clin. Nurs. Res., 11(4):41732, 2002.

Datta Banik, S. Arm span as a proxy measure for height and estimation of nutritional status: a study among Dhimals of Darjeeling in West Bengal India. Ann. Hum. Biol., 38(6):728-35, 2011.

Fatmah, F. Diagnostic test of predicted height model in Indonesian elderly: a study in an urban area. Med. J. Indones., 19(3):199-204, 2010.

Fredriks, A. M.; van Buuren, S.; van Heel, W. J. M.; Dijkman-Neericx, R. H. M.; Verloove-Vanhorich, S. P. \& Wit, J. M. Nationwide age references for sitting height, leg length, and sitting height/height ratio, and their diagnostic value for disproportionate growth disorders. Arch. Dis. Child., 90(8):807-12, 2005.

Gardasevic, J. Relationship between sitting height measurements and standing height: a prospective regional study among adolescents in eastern region of Kosovo. Sport Mont, 16(2):15-9, 2018.

Gardasevic, J. Standing height and its estimation utilizing tibia length measurements in adolescents from Western Region in Kosovo. Int. J. Morphol., 37(1):227-31, 2019.

Gardasevic, J.; Masanovic, B. \& Arifi, F. Relationship Between Tibia Length Measurements and Standing Height: A Prospective Regional Study Among Adolescents in Northern Region of Kosovo. Anthropologie, 57(3):2639, 2019.

Gardasevic, J.; Rasidagic, F.; Krivokapic, D.; Corluka, M. \& Bjelica, D. Stature and Its Estimation Utilizing Arm Span Measurements in Male Adolescents from Federation of Bosnia and Herzegovina Entity in Bosnia and Herzegovina. Monten. J. Sports Sci. Med., 6(1):37-44, 2017.

Grasgruber, P.; Prce, S.; Stracarova, N.; Hrazdíra, E.; Cacek, J.; Popovic, S.; Hrebíckova, S.; Potpara, P.; Davidovic, I. \& Kalina, T. The coast of giants: an anthropometric survey of high schoolers on the Adriatic coast of Croatia. PeerJ, 7:e6598, 2019.

Harris, J. A. \& Benedict, F. G. A biometric study of human basal metabolism. Proc. Natl. Acad. Sci., 4(12):370-3, 1918.

Jakhar, J. K.; Pal, V. \& Paliwal, P. K. Estimation of height from measurements of foot length in Haryana region. J. Indian Acad. Forensic Med., 32(3):231-3, 2010.

Kanchan, T.; Menezes, R. G.; Moudgil, R.; Kaur, R; Kotian, M. S. \& Garg, R. K. Standing height estimation from foot dimensions. Forensic Sci. Int., $179(2-3): 241 \mathrm{e} 1-245 \mathrm{e} 1,2008$.

Kubota, M.; Kobayashi, H.; Quanjer, P.H.; Omori, H.; Tatsumi, K. \& Kanazawa, M. Reference values for spirometry, including vital capacity, in Japanese adults calculated with the LMS method and compared with previous values. Respir. Investig., 52(4):242-50, 2014.

Leung, S. S. F.; Lau, J. T. F.; Xu, Y. Y.; Tse, L. Y.; Huen, K. F.; Wong, G. W. K.; Law, W. Y.; Yeung, V. T. F.; Yeung, W. K. Y. \& Leung, N. K. Secular changes in standing height, sitting height and sexual maturation of Chinese-The Hong Kong growth study, 1993. Ann. Hum. Biol., 23(4):297306, 1996.

Marfell-Jones, M.; Olds, T.; Stew, A. D. \& Carter, J. E. L. International Standards for Anthropometric Assessment. Potchesfstroom, International Society for the Advancement of Kinanthropometry; 2006.

Masanovic, B.; Arifi, F. \& Gardasevic, J. Standing height and its estimation utilizing sitting height measurements in adolescents from the western region in Kosovo. Sport Mont, 17(3):3-7, 2019c.

Masanovic, B.; Bavcevic, T. \& Prskalo, I. Regional differences in adult body height in Kosovo. Monten. J. Sports Sci. Med., 8(1):69-76, 2019a.

Masanovic, B.; Gardasevic, J. \& Arifi F. Relationship between foot length measurements and standing height: a prospective regional study among adolescents in southern region of Kosovo. Sport Mont, 16(2):27-31, 2018.

Masanovic, B.; Gardasevic, J. \& Arifi, F. Relationship between foot length measurements and body height: a prospective regional study among adolescents in Northern Region of Kosovo. Anthropologie, 57(2):227$33,2019 b$.
Masanovic, B.; Popovic, S.; Jarani, J.; Spahi, A. \& Bjelica, D. Nationwide stature estimation from armspan measurements in Albanian youngsters. Int. J. Morphol., 38(2):382-8, 2020.

Mohanty, S. P.; Babu, S. S. \& Nair, N. S. The use of arm span as a predictor of height. A study of South Indian women. J. Orthop. Surg. (Hong Kong), 9(1):19-23, 2001.

Mustafa, B.; Hajdari, A.; Krasniqi, F.; Hoxha, E.; Ademi, H.; Quave, C.L. \& Pieroni, A. Medical ethnobotany of the Albanian Alps in Kosovo. $J$. Ethnobiol. Ethnomed., 8(1):6, 2012.

Popovic, S. Local geographical differences in adult body height in Montenegro. Monten. J. Sports Sci. Med., 6(1):81-7, 2017.

Popovic, S. Nationwide stature estimation from sitting height measurements in Kosovan adolescents. Int. J. Morphol., 37(2):504-8, 2019.

Popovic, S.; Bjelica, D.; Molnar, S.; Jaksic, D. \& Akpinar, S. body height and its estimation utilizing arm span measurements in Serbian adults. Int. J. Morphol., 31(1):271-9, 2013.

Popovic, S.; Bjelica, D.; Tanase, G. D. \& Milasinovic, R. Body Height and Its Estimation Utilizing Arm Span Measurements in Bosnian and Herzegovinian Adolescents. Monten. J. Sports Sci. Med., 4(1):29-36, 2015.

Popovic, S.; Gardasevic, J.; Masanovic, B.; Arifi, F. \& Bjelica, D. Standing Height and its Estimation Utilizing Foot Length Measurements in Adolescents from Western Region in Kosovo. Sport Mont, 15(3):3-7, 2017.

Quanjer, P. H.; Capderou, A.; Mazocioglu, M. M.; Aggarwal, A.; Popovic, S.; Datta Banik, S.; Tayie, F. A. K.; Golshan, M.; Ip, M. S. M. \& Zelter, M. All-age relationship between arm span and height in different ethnic groups. Eur. Respir. J., 44(4):905-12, 2014.

Reeves, S. L.; Varakamin, C. \& Henry, C. J. The relationship between armspan measurements and height with special reference to gender and ethnicity. Eur. J. Clin. Nutr., 50(6):398-400, 1996.

Starc, G.; Popovic, S.; ordic, V.; Ostojic, S.; Music Milanovic, S.; Kujundzic, E.; Spiroski, I.; uric, S.; Masanovic, B.; Sember, V.; et al. Differences in body height between the contemporary Western Balkan children and the WHO growth references core sample. Anthropol. Noteb., 25(3):55-67, 2019.

Steele, M. F. \& Chenier, T. C. Arm-span, height and age in black and white women. Ann. Hum. Biol., 17(6):533-41, 1990.

Szollosi, E. Secular trend in Debrecen university students (in Hungerian). Anthropol. Közl., 39:43-51, 1998.

Tanner, J. M.; Hayashi, T.; Preece, M.A. \& Cameron, N. Increase in length of leg relative to trunk in Japanese children and adults from 1957 to 1977: comparison with British and with Japanese Americans. Ann. Hum. Biol., 9(5):411-23, 1982.

Ukwuma, M. A. study of the Cormic index in a southeastern Nigerian population. Internet J. Biol. Anthropol., 4(1):1-6, 2009.

Wronka, I. \& Pawlinska-Chmara, R. Childhood environment and adult height among Polish university students. Coll. Antropol., 33(4):1039-45, 2009.

\section{Corresponding author: \\ Bojan Masanovic, PhD \\ University of Montenegro \\ Faculty for Sport and Physical Education \\ Narodne omladine bb \\ 81400 Niksic \\ MONTENEGRO}

\section{Email: bojanma@ucg.ac.me}

